OPEN ACCESS

Edited by:

Angel Nadal,

Universidad Miguel Hernández de

Elche, Spain

Reviewed by:

Luis Miguel Garcia-Segura,

Spanish National Research Council

(CSIC), Spain

Tanja Adam,

Maastricht University, Netherlands

${ }^{*}$ Correspondence:

GianCarlo Panzica giancarlo.panzica@unito.it

Specialty section:

This article was submitted to Systems and Translational

Endocrinology,

a section of the journa

Frontiers in Endocrinology

Received: 23 September 2018 Accepted: 06 December 2018

Published: 09 January 2019

Citation:

Marraudino $M$, Bonaldo $B$, Farinetti $A$, Panzica G, Ponti G and Gotti S (2019) Metabolism Disrupting Chemicals and Alteration of Neuroendocrine Circuits Controlling Food Intake and Energy Metabolism. Front. Endocrinol. 9:766. doi: 10.3389/fendo.2018.00766

\section{Metabolism Disrupting Chemicals and Alteration of Neuroendocrine Circuits Controlling Food Intake and Energy Metabolism}

\author{
Marilena Marraudino ${ }^{1,2}$, Brigitta Bonaldo ${ }^{1,2}$, Alice Farinetti ${ }^{1,2}$, GianCarlo Panzica ${ }^{1,2 *}$, \\ Giovanna Ponti ${ }^{1,3}$ and Stefano Gotti ${ }^{1,2}$ \\ ${ }^{1}$ Neuroscience Institute Cavalieri Ottolenghi, Turin, Italy, ${ }^{2}$ Department of Neuroscience "Rita Levi-Montalcini", University of \\ Turin, Turin, Italy, ${ }^{3}$ Department of Veterinary Sciences, University of Turin, Turin, Italy
}

The metabolism-disrupting chemicals (MDCs) are molecules (largely belonging to the category of endocrine disrupting chemicals, EDCs) that can cause important diseases as the metabolic syndrome, obesity, Type 2 Diabetes Mellitus or fatty liver. MDCs act on fat tissue and liver, may regulate gut functions (influencing absorption), but they may also alter the hypothalamic peptidergic circuits that control food intake and energy metabolism. These circuits are normally regulated by several factors, including estrogens, therefore those EDCs that are able to bind estrogen receptors may promote metabolic changes through their action on the same hypothalamic circuits. Here, we discuss data showing how the exposure to some MDCs can alter the expression of neuropeptides within the hypothalamic circuits involved in food intake and energy metabolism. In particular, in this review we have described the effects at hypothalamic level of three known EDCs: Genistein, an isoflavone (phytoestrogen) abundant in soy-based food (a possible new not-synthetic MDC), Bisphenol A (compound involved in the manufacturing of many consumer plastic products), and Tributyltin chloride (one of the most dangerous and toxic endocrine disruptor, used in antifouling paint for boats).

Keywords: metabolic disruptor, food intake, hypothalamus, estrogens, bisphenol A, tributyltin, genistein

\section{THE HYPOTHALAMIC CONTROL OF FOOD-INTAKE AND ENERGY METABOLISM}

The hypothalamus plays an essential role in controlling food intake and energetic status, mainly through two antagonistic neuronal populations of the hypothalamic arcuate nucleus (ARC): the orexigenic neurons (appetite-stimulating), characterized by the co-expression of agoutirelated peptide (AgRP) and neuropeptide $\mathrm{Y}(\mathrm{NPY})$, and the anorexigenic neurons (appetitesuppressing) that co-express pro-opiomelanocortin (POMC) and cocaine- and amphetamineregulated transcript (CART) (1-4) (Figure 1). These ARC neurons project to other hypothalamic nuclei, among which the Ventromedial hypothalamic (VMH), and the Paraventricular (PVN) nuclei (Figure 1). The latter one is the most important center of metabolic control: it integrates orexigenic and anorexigenic inputs from ARC and modulates energy expenditure through the hypothalamic pituitary adrenal (HPA)-axis (5), and the hypothalamic pituitary thyroid (HPT)-axis $(6,7)$. 


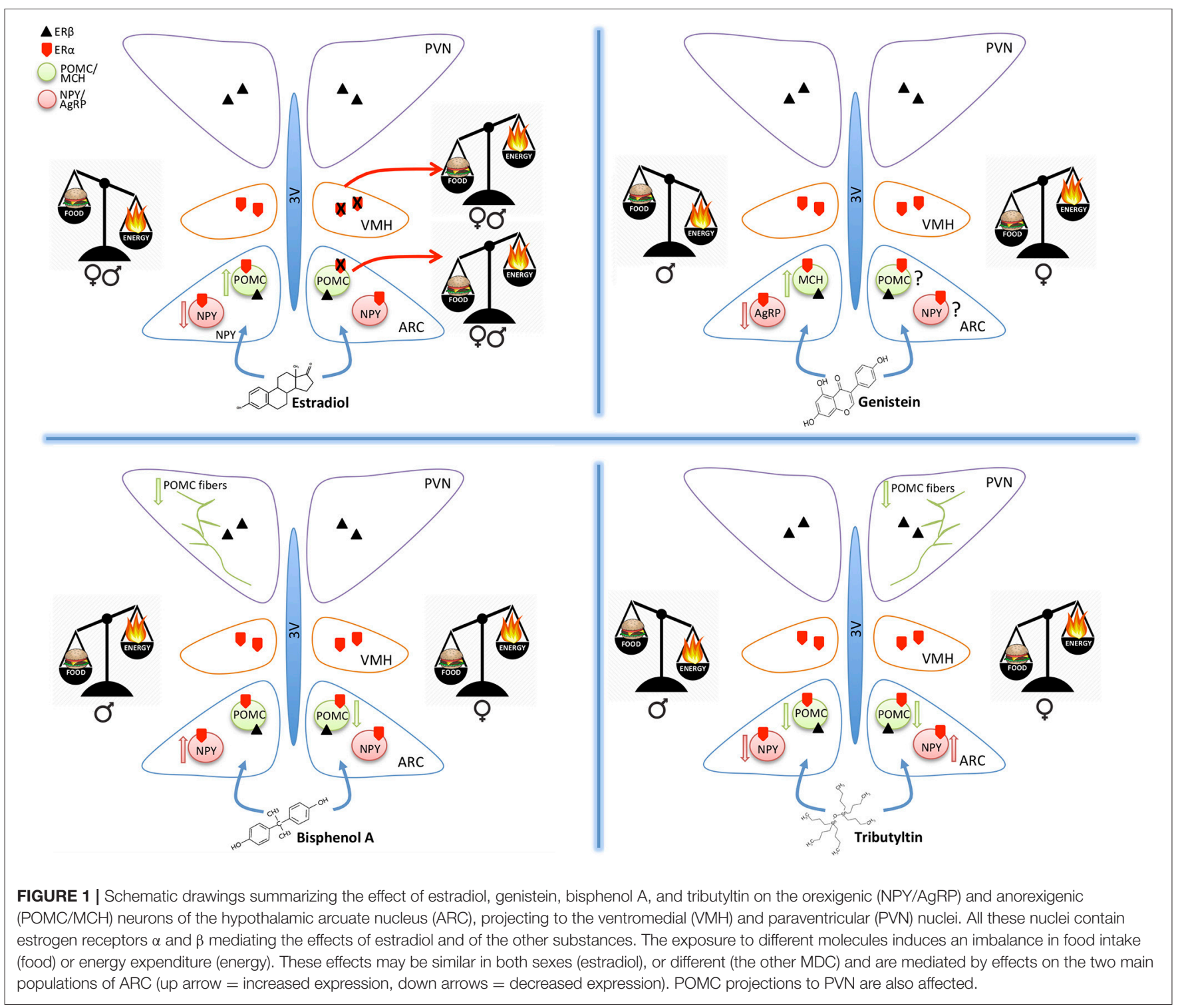

These systems are sensitive to peripheral signals of energetic balance (for example leptin, insulin, and GHrelin). Leptin blood levels depend on the size of fat stores (8) and acts as an anorexigenic factor to adjust energy requirements, fat reserves, and food intake (9). In contrast, GHrelin has an orexigenic role in the central control of appetite and metabolism (10). Moreover, also sexual hormones, thyroid hormones, and growth factors can modulate the hypothalamic circuits regulating appetite, satiety, and metabolism (11). In particular, in mammals, estradiol $\left(\mathrm{E}_{2}\right)$ has an important role on the regulation of food intake and metabolism with an appetite-suppressing effect $(12,13)$.

Several synthetic or natural molecules that are present in the environment may interact with the estrogen or androgen signaling chain (xenoestrogens, xenoandrogens) and have been classified as endocrine disrupting chemicals [EDCs, (14)]. In addition, many of these EDCs have been considered to belong to the category of metabolism disrupting chemicals (see below), however, little attention has been dedicated, until now, to their action of neural circuits controlling food intake and energy metabolism.

\section{CENTRAL ACTION OF METABOLISM-DISRUPTING CHEMICALS (MDCS)}

The metabolism-disrupting chemicals (MDCs) have been defined (Parma Consensus Statement, (15) as those endocrine disrupting chemicals (EDCs) that are able to promote metabolic changes that can result in obesity, Type 2 Diabetes Mellitus (T2DM) or fatty liver in animals including humans. The major targets for these compounds are the fat tissue and the liver (11), however, they may regulate nutrient ingestion and metabolism by altering 
intestinal transport, secretion of gut peptides, composition of the gut microbiota as well as the expression of hypothalamic neuropeptides that control food intake $(11,16)$. Several studies reported that MDCs can alter food intake, with different effects based on dose, timing, and exposure duration (17-19). In particular, exposure to MDCs during the perinatal period and/or adulthood modifies the cues that regulate energy homeostasis, such as serum levels of insulin, leptin, and fatty acids (20).

In this short review, we will describe the neuroendocrinological effects of a possible new, not-synthetic, MDC (Genistein), and of two synthetic identified MDCs (Bisphenol A and Tributyltin), (Table 1).

\section{Genistein}

Soy isoflavones, in particular Genistein (GEN), are very abundant in soy-based food (28) and are an important source of EDCs (29). GEN action requires both estrogen receptor (ER) $\alpha$ and ER $\beta$ (30), although, compared to $\mathrm{E}_{2}, \mathrm{GEN}$ affinity is low for $\mathrm{ER} \alpha$, while it is similar for ER $\beta$ (31-33). ER $\alpha$ is required for GEN effect in females and ER $\beta$, as well as PPAR $\gamma$, in males $(34,35)$. Even if the sensitivity of the hypothalamus to GEN is well-acknowledged $(36,37)$, very little is known on neuronal circuits controlling energetic metabolism.

In vitro, GEN induces adipocytes' apoptosis, decreases lipid accumulation, and increases lipolysis. Moreover, GEN decreases leptin synthesis (38) and inhibits its secretion (39). In vivo, GEN effect depends on sex $(40,41)$ and on the administered dose (42). In females, an anti-obesogenic effect of GEN is reported for many obese mouse models $(43,44)$, in juvenile and adult ovariectomized $(45,46)$ and intact mice $(34)$. This effect is dose dependent (42): GEN inhibits adipogenesis at low concentrations and enhances it at high concentrations $(47,48)$. GEN effect on fat pad weight is opposite in males, with an obesogenic effect at low doses $(34,35,49)$ and an antiobesogenic effect at high doses (34). The effect of GEN during perinatal development may be very different: many studies report an obesogenic effect (50, 51), although only in females (52), while others report an anti-obesogenic effect in males $(21,53)$. GEN effect during development may be due to epigenetic modifications in the offsprings (54) or to an alteration of the development of estrogen sensitive circuits regulating energetic metabolism, as for other MDCs (11). In fact, GEN is able to affect neural circuits controlling animal welfare and fertility $(36,37)$, although little is known about its effects on neuronal circuits controlling energetic metabolism. A previous study (21) addressed the effect of soy phytoestrogens, daidzein, and genistein, on the hypothalamus of male mice, reporting that high phytoestrogens levels throughout embryonal and postnatal life decrease AgRP and increase $\mathrm{MCH}$, orexin A and TRH mRNA levels, but it has no effect on NPY, POMC, and CART expression [(21), Figure 1]. While, our ongoing study in male and female mice demonstrates that early postnatal exposure to GEN, in a dose comparable to exposure level in babies fed with soy-based formula, determines an obesogenic phenotype in adult females and a long-term sex specific effects on hypothalamic kiss, POMC and Orexin systems (55). Early post-natal administration of GEN is also influencing the differentiation of other neural circuits in mice not directly related to the control of metabolism (i.e., nitrergic, vasopressinergic, and dopaminergic circuits, [(36), Ponti et al. submitted].

GEN effect on humans is not clear (56). GEN metabolism and bioavailability depends on gut microbioma (57) and GEN exposure may be highly affected by vegan/vegetarian diets (58). The use of soy-based meal replacement formula was effective in lowering body weight and fat mass and reducing LDL cholesterol in obese individuals and together with physical exercise has a beneficial effect on leptin levels in postmenopausal women (59). In contrast, healthy, normal-weight postmenopausal women did not show improvement in metabolic parameters when given high-dose isoflavones (60).

The complexity of the data on the animal and epidemiological studies on the regulation of energetic metabolism, as well as on other neuronal circuits indicate that GEN is a powerful natural compound which may have at the same time highly beneficial or detrimental effects (37) which are worth to be investigated in more detail. Moreover, the contradictory experimental data underline the importance of considering the timing of exposure, the dose/concentration, the sex, and the species-specificity when establishing safety recommendations for dietary GEN intake, especially if in early-life.

\section{Bisphenol A}

Since 1930s, Bisphenol A (BPA) has been involved in the manufacturing of many consumer products [e.g., plastics, PVC, food packaging, thermal papers, (61)]. Thanks to its structure, BPA interacts with a variety of hormone receptors (22): $\mathrm{ER} \alpha$, ER $\beta$, GPR30, and estrogen-related receptor $\gamma[\operatorname{ERR} \gamma,(22)]$. Moreover, BPA could also interact with androgen receptor (AR), peroxisome proliferator-activated receptor $\gamma$ (PPAR $\gamma)$, glucocorticoid receptor (GR), and thyroid hormone receptors [THs, (22)]. These findings strongly suggest that BPA is a multitarget compound that can act on a wide range of hormonesensitive elements. In fact, BPA has been described also as MDC and the evidences of its role in the alterations of the metabolic axis are increasing (11).

BPA potential obesogenic effects are related to alteration of peripheral parameters, such as weight gain, modifications of leptin or insulin plasma levels, or alterations in the adipose tissue [for a recent review see (62)]. Few studies investigated BPA effects on hypothalamic systems controlling food intake and energy homeostasis, and they are mainly focused on the perinatal exposure (18). BPA exposure of mice from gestational day 0 to Post Natal Day (PND) 21 through diet (1 or $20 \mu \mathrm{g} \mathrm{BPA} / \mathrm{kg}$ diet) in combination with HFD had a sexually dimorphic effect on hypothalamic circuits: in males, it impairs glucose tolerance, reduces $\mathrm{POMC}$ fiber innervation in the $\mathrm{PVN}$ and, in combination with HFD, increases NPY and AgRP expression in the ARC. In females, BPA induces a weight gain, increases food intake, adiposity, and leptin blood levels, while in combination with HFD reduces POMC mRNA expression in the ARC (18). Taken together these data support the idea that BPA acts as a MDC in a sexually dimorphic way [(22), Figure 1].

Gestational BPA exposure (5 mg/L BPA through drinking water) of Sprague-Dawley rat dams increases the proliferation 


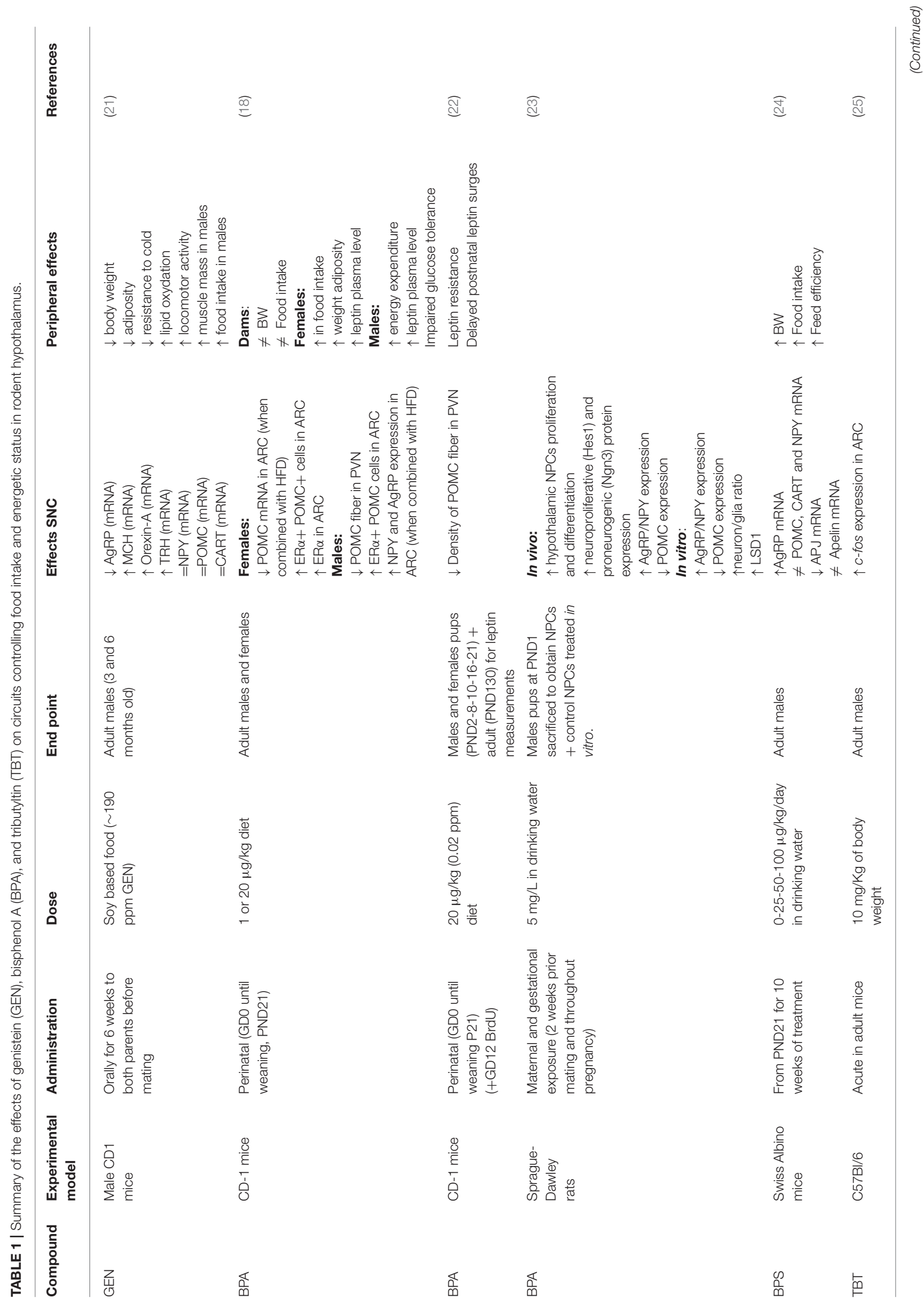




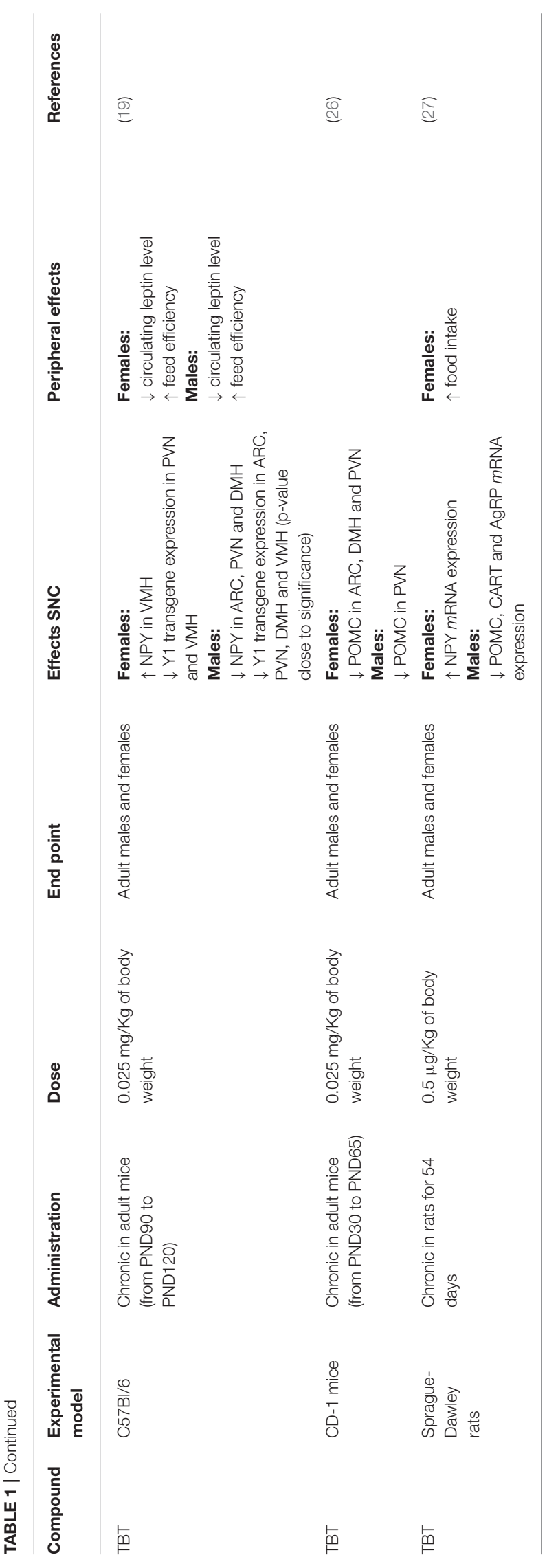

and differentiation of cultured primary hypothalamic neural progenitors (NPCs), as well as the expression of AgRP, while the expression of POMC is reduced (23). BPA is also acting on the kiss system in both rats (63) and mice (64), inducing sexually dimorphic alterations in the cell number of ARC and preoptic populations. Moreover, perinatal treatment with BPA decreases the percentage of kisspeptin-ir fibers in PVN during the postnatal development in female mice (65).

While studies on BPA effects are slowly increasing, only a few studies focus on BPA-analogs: postnatal exposure from PND21 for 10 weeks with $25-50-100 \mu \mathrm{g} / \mathrm{kg}$ BW/day of bisphenol S (BPS) in drinking water affects orexigenic hypothalamic systems resulting in a dose-dependent increase of AgRP mRNA level but not in NPY one or in anorexigenic neuropeptides [POMC, CART; (24)].

Considering the complex relationships between the different circuits involved in the control of food intake and energy homeostasis, further studies are needed to clarify all the effects related to the exposure to BPA and to its less described analogs. In fact, after recognizing the EDC's properties of BPA (66), the search for an appropriate substitute became a fundamental problem to solve. At present, more than $15 \mathrm{BP}$ analogs have been synthesized $(67,68)$ but none is a real solution. The safety of two of the most used BPA substitutes, BPS and bisphenol F, still remain unclear: in vitro and in vivo studies, suggests that they share with BPA not only the endocrine-disrupting properties but also the metabolic disrupting ones (69-71).

Both GEN and BPA share a common xenoestrogenic activity, therefore it is possible that they may exert their action altering the estrogens' action on metabolism regulation. In fact, in mammals estradiol $\left(E_{2}\right)$ has an important role on the regulation of food intake and metabolism with an appetite-suppressing effect (12, 13). In female rodents, ovariectomy (OVX) induces an increased body weight and hyper-adiposity, $\mathrm{E}_{2}$ treatment can robustly inhibit food intake $(72,73)$. Similarly, in our species, women report a decrease in appetite during the periovulatory stage of ovarian cycle, when $\mathrm{E}_{2}$ reach a maximal peak $(12,74)$, while, the development of obesity, type II diabetes and metabolic syndrome in menopause has been correlated with the low $\mathrm{E}_{2}$ level $(75,76)$. These metabolic diseases are partially reverted by $\mathrm{E}_{2}$ replacement therapy $(77,78)$.

$\mathrm{E}_{2}$ action is mediated by ERs, in particular, the intracellular $\mathrm{ER} \alpha$, may affect different aspects of regulation of food intake and energy metabolism. This is confirmed by the observation that in rodents deletion of ER $\alpha$ gene cause obesity (79) and the blockage of the appetite-suppressing effect of $\mathrm{E}_{2}$ treatment (73). In humans, the polymorphisms in the estrogen receptor alpha gene have been associated with body fat distribution (80). The suppression of $\mathrm{ER} \alpha$ expression in $\mathrm{VMH}$ alters the anorexigenic effect of $\mathrm{E}_{2}$ treatment, leading to obesity, hyperphagia, and reduced energy expenditure in female mice and rats [(81), Figure 1].

Moreover, in ARC and VMH, many neurons co-express $\mathrm{ER} \alpha$ and the isoform b of leptin receptor (LepRb) (82). Leptin levels are correlated with $\mathrm{E}_{2}$ fluctuation: a decrease of $\mathrm{E}_{2}$ reduces leptin secretion, which can be restored by $\mathrm{E}_{2}$ treatment (83). Furthermore, both gonadal hormones $(84,85)$ and leptin $(86)$ 
modulate Kisspeptin (kiss) anorexigenic neurons. In fact, kiss peptide, co-localizes with $\mathrm{ER} \alpha$ (87) and LepRb (88) in ARC. Reciprocal connections link kiss cells, NPY and POMC neurons (89): Kiss excites POMC system directly through the kiss receptor (GPR54) expressed by POMC neurons (90) and inhibits NPY neurons indirectly by enhancing GABA-mediated inhibitory synaptic tone (91). Therefore, hypothalamic kiss system may be a good target for $E_{2}$ in the regulation of food intake and energy metabolism along with the well-known control of reproduction.

Few studies analyzed sexual dimorphism on feeding circuits. The World Health Organization (WHO) reported that the obesity prevalently affects women, and it reaches at twice the rates of men in some regions of the world (92). $E_{2}$ has an important anorexigenic role also in males: the deletion of $\mathrm{ER} \alpha$ in mice, $(79,93)$, as well as the mutation of $\mathrm{ER} \alpha$ in men, causes obesity $(94,95)$ (Figure 1). Moreover, $\mathrm{E}_{2}$ treatment in males reduces body weight $(4,96)$. Sexual dimorphism is reported also for NPY and POMC systems $(97,98)$ and for their receptors (99-101).

These data support the hypothesis that the metabolic disrupting properties of GEN and BPA as well as of other xenoestrogens are based on their ability in interfering with the estrogenic regulation of metabolism and food intake [reviewed in (11)].

\section{Tributyltin}

Organotin chemicals are compounds containing at least one bond between tin and carbon. The most studied is Tributyltin chloride (TBT), one of the most dangerous and toxic EDC presents in the environment acting as MDC at both peripheral (102) and central level [for recent reviews see (103-106)]. Due to its primarily use in antifouling paint for boats (94), TBT exerted toxicological effects on marine organisms. As a result, fish and fishery products are the main source of human exposure.

Unlike GEN and BPA, Tributyltin chloride (TBT) is an androgen agonist (it binds ARs), while it has no affinity for $\mathrm{ER} \alpha$ (107). More recently, TBT has been identified as agonist ligand for RXR and PPAR $\gamma$ (108) and as a promoter of adipogenesis, favoring obesity (109). In fact, PPAR $\gamma$ and $\mathrm{RXR} \gamma$ are strongly express within hypothalamus (110) by nuclei interesting in metabolic and food intake control (as VMH, LH, PVN). Moreover, blocking with pharmacological antagonists or with shRNA the central endogenous activation of PPAR $\gamma$ led to negative energy balance, restored leptin-sensitivity in high-fat diet (HFD)-fed rats (111).

Acute exposure to TBT induced a significant increase of cell expressing c-fos in the ARC nucleus in adult mice (25), thus suggesting a direct action of TBT at the hypothalamic level. A few other studies confirmed this observation. In fact, a chronical exposure to TBT induced a diminution of NPY expression in adult male but not in female mice, a decrease of circulating leptin level, and a decrease of Y1 receptor transgene expression in both sexes (19). Also the POMC immunoreactive system was influenced (26) with a significant decrease of POMC-positive structures in female mice only (Figure 1).

In rats, TBT exposure increased significantly NPY expression in the female together with an increase of food intake, while male presented a decrease of AgRP and CART and appetite (27). Another interesting study in rats investigated whether TBT dependent metabolic disorders were correlated with abnormal hypothalamus-pituitary-gonadal (HPG) axis function, as well as kisspeptin action: after a chronic treatment with TBT, female showed metabolic dysfunctions and HPG axis abnormalities, providing evidence that TBT leads to toxic effects direct on the HPG axis and/or indirectly by abnormal metabolic regulation of the HPG axis (112). TBT has an action also on the hypothalamicpituitary-adrenal (HPA) axis function (113): a recent study showed that, in female rats, TBT disrupts the morphophysiology of the HPA, leading to an increase in CRH mRNA expression, a decrease in ACTH release and an increase in corticosterone levels (114). Moreover, many studies in vivo and in vitro have shown TBT effects also on the thyroid morphophysiology and the homeostasis of hypothalamus-pituitary-thyroid axis. TBT may act altering T3 and T4 level $(115,116)$, down-regulating of thyroid peroxidase, and up-regulating of the thyroid-stimulating hormone receptor (117). TBT given to pregnant mice induces hypothyroidism in the progeny, and induces a dose-dependent increase of T3-independent TRH transcription levels in the hypothalamus of dams (118).

Experimental and epidemiological evidence suggest that the gut microbiota is responsible for significant immunologic, neuronal and endocrine changes that lead to obesity (119), and, recently, it was demonstrated that TBT affect the microbiota system in treated mice, inducing dyslipidemia (120).

In conclusion, TBT has strong effects on both the periphery, with its effects on the mechanisms promoting adipogenesis (121, 122 ) and the brain by altering the hypothalamic neuroendocrine centers regulating food intake and metabolism $(19,26,105,123)$. All data collected up to now strongly suggest that TBT is a potent MDC.

\section{CONCLUSION}

In recent years, obesity and metabolic syndromes are increased; even if it is necessary to consider the possible genetic predispositions, and the excessive food intake without appropriate physical exercise, probably the causes should be sought also in numerous natural or synthetic substances that pervade our environment, known as MDCs.

While the possible role as metabolic disruptors of these substances, in particular BPA and TBT, is widely recognized both at hypothalamic and peripheral level, the GEN effect remains controversial on a peripheral level and still unclear, on the hypothalamic neuroendocrine circuits involved in food intake. Therefore, more studies are needed to clarify the interference of these compounds on the complex neural circuit that controls food intake and metabolism.

\section{AUTHOR CONTRIBUTIONS}

All the authors searched the bibliography. MM wrote a first draft, all the other authors checked for specific part of the manuscript. SG and GCP coordinated the final manuscript. 


\section{FUNDING}

This study was supported by Ministero dell'Istruzione, dell'Università e della Ricerca-MIUR project Dipartimenti di Eccellenza 2018-2022 to Department of Neuroscience Rita

\section{REFERENCES}

1. Gropp E, Shanabrough M, Borok E, Xu AW, Janoschek R, Buch T, et al. Agouti-related peptide-expressing neurons are mandatory for feeding. Nat Neurosci. (2005) 8:1289-91. doi: 10.1038/nn1548

2. Balthasar N, Dalgaard LT, Lee CE, Yu J, Funahashi H, Williams T, et al. Divergence of melanocortin pathways in the control of food intake and energy expenditure. Cell (2005) 123 493-505. doi: 10.1016/j.cell.2005.08.035

3. Timper K, Bruning JC. Hypothalamic circuits regulating appetite and energy homeostasis: pathways to obesity. Dis Model Mech. (2017) 10:679-89. doi: $10.1242 / \mathrm{dmm} .026609$

4. Gao Q, Horvath TL. Neurobiology of feeding and energy expenditure. Annu Rev Neurosci. (2007) 30:367-98. doi: 10.1146/annurev.neuro.30.051606. 094324

5. van Swieten MM, Pandit R, Adan RA, van der Plasse G. The neuroanatomical function of leptin in the hypothalamus. J Chem Neuroanat. (2014) 6162:207-20. doi: 10.1016/j.jchemneu.2014.05.004

6. Leibowitz SF, and Wortley KE, Hypothalamic control of energy balance: different peptides, different functions. Peptides (2004) 25:473-504. doi: 10.1016/j.peptides.2004.02.006

7. Lechan RM, Fekete C. Role of melanocortin signaling in the regulation of the hypothalamic-pituitary-thyroid (HPT) axis. Peptides (2006) 27:310-25. doi: 10.1016/j.peptides.2005.01.033

8. Halaas JL, Gajiwala KS, Maffei M, Cohen SL, Chait BT, Rabinowitz D, et al. Weight-reducing effects of the plasma protein encoded by the obese gene. Science (1995) 269:543-6. doi: 10.1126/science.7624777

9. Casanueva FF, Dieguez C. Neuroendocrine regulation and actions of leptin. Front Neuroendocrinol. (1999) 20:317-63. doi: 10.1006/frne.1999.0187

10. Solomou S, Korbonits M. The role of ghrelin in weight-regulation disorders: implications in clinical practice. Hormones (2014) 13:458-75. doi: 10.14310/horm.2002.1551

11. Heindel JJ, Blumberg B, Cave M, Machtinger R, Mantovani A, Mendez $\mathrm{MA}$, et al. Metabolism disrupting chemicals and metabolic disorders. Reprod Toxicol (2017) 68:3-33. doi: 10.1016/j.reprotox.2016.10.001

12. Martinez de Morentin PB, Gonzalez-Garcia I, Martins L, Lage R, FernandezMallo D, Martinez-Sanchez N, et al. Estradiol regulates brown adipose tissue thermogenesis via hypothalamic AMPK. Cell Metab. (2014) 20 41-53. doi: 10.1016/j.cmet.2014.03.031

13. Martinez de Morentin PB, Lage R, Gonzalez-Garcia I, Ruiz-Pino F, Martins L, Fernandez-Mallo D, et al. Pregnancy induces resistance to the anorectic effect of hypothalamic malonyl-CoA and the thermogenic effect of hypothalamic AMPK inhibition in female rats. Endocrinology (2015) 156:947-60. doi: 10.1210/en.2014-1611

14. Zoeller RT, Brown TR, Doan LL, Gore AC, Skakkebaek NE, Soto AM, et al. Endocrine-disrupting chemicals and public health protection: a statement of principles from The Endocrine Society. Endocrinology (2012) 153:4097-110. doi: 10.1210/en.2012-1422

15. Heindel JJ, Vom Saal FS, Blumberg B, Bovolin P, Calamandrei G, Ceresini $\mathrm{G}$, et al. Parma consensus statement on metabolic disruptors. Environ Health (2015) 14:54. doi: 10.1186/s12940-015-0042-7

16. Nadal A, Quesada I, Tuduri E, Nogueiras R, Alonso-Magdalena P. Endocrine-disrupting chemicals and the regulation of energy balance. Nat Rev Endocrinol. (2017) 13:536-46. doi: 10.1038/nrendo.2017.51

17. Angle BM, Do RP, Ponzi D, Stahlhut RW, Drury BE, Nagel SC, et al. Metabolic disruption in male mice due to fetal exposure to low but not high doses of bisphenol A (BPA): evidence for effects on body weight, food intake, adipocytes, leptin, adiponectin, insulin and glucose regulation. Reprod Toxicol. (2013) 42:256-68. doi: 10.1016/j.reprotox.2013.07.017
Levi Montalcini and Department of Veterinary Science; University of Torino, Ricerca locale to GP, GCP, SG, and Cavalieri-Ottolenghi Foundation, Orbassano, Italy. MM fellowship was generously granted by Prof. G.C. Bergui.

18. Mackay H, Patterson ZR, Khazall R, Patel S, Tsirlin D, Abizaid A. Organizational effects of perinatal exposure to bisphenol-A and diethylstilbestrol on arcuate nucleus circuitry controlling food intake and energy expenditure in male and female CD-1 mice. Endocrinology (2013) 154:1465-75. doi: 10.1210/en.2012-2044

19. Bo E, Farinetti A, Marraudino M, Sterchele D, Eva C, Gotti S, et al. Adult exposure to tributyltin affects hypothalamic neuropeptide Y, Y1 receptor distribution, and circulating leptin in mice. Andrology (2016) 4:723-34. doi: $10.1111 /$ andr.12222

20. Stern JH, Rutkowski JM, Scherer PE. Adiponectin, leptin, and fatty acids in the maintenance of metabolic homeostasis through adipose tissue crosstalk. Cell Metab. (2016) 23:770-84. doi: 10.1016/j.cmet.2016.04.011

21. Cederroth CR, Vinciguerra M, Kuhne F, Madani R, Doerge DR, Visser TJ, et al. A phytoestrogen-rich diet increases energy expenditure and decreases adiposity in mice. Environ Health Perspect. (2007) 115:1467-73. doi: $10.1289 /$ ehp.10413

22. MacKay H, Patterson ZR, Abizaid A. Perinatal exposure to lowdose bisphenol-a disrupts the structural and functional development of the hypothalamic feeding circuitry. Endocrinology (2017) 158:768-77. doi: 10.1210/en.2016-1718

23. Desai M, Ferrini MG, Han G, Jellyman JK, Ross MG. In vivo maternal and in vitro BPA exposure effects on hypothalamic neurogenesis and appetite regulators. Environ Res. (2018) 164:45-52. doi: 10.1016/j.envres.2018.02.011

24. Rezg R, Abot A, Mornagui B, Aydi S, Knauf C. Effects of bisphenol $\mathrm{S}$ on hypothalamic neuropeptides regulating feeding behavior and apelin/APJ system in mice. Ecotoxicol Environ Saf. (2018) 161:459-66. doi: 10.1016/j.ecoenv.2018.06.001

25. Bo E, Viglietti-Panzica C, Panzica GC. Acute exposure to tributyltin induces c-fos activation in the hypothalamic arcuate nucleus of adult male mice. Neurotoxicology (2011) 32:277-80. doi: 10.1016/j.neuro.2010.12.011

26. Farinetti A, Marraudino M, Ponti G, Panzica G, Gotti S. Chronic treatment with tributyltin induces sexually dimorphic alterations in the hypothalamic POMC system of adult mice. Cell Tissue Res. (2018). 374:58794 doi: 10.1007/s00441-018-2896-9

27. He K, Zhang J, Chen Z. Effect of tributyltin on the food intake and brain neuropeptide expression in rats. Endokrynol Pol. (2014) 65:485-90. doi: 10.5603/EP.2014.0068

28. Whitten PL, Patisaul HB. Cross-species and interassay comparisons of phytoestrogen action. Environ Health Perspect. (2001) 109 (Suppl. 1) 5-20. doi: 10.1289/ehp.01109s15

29. Thigpen JE, Setchell KD, Saunders HE, Haseman JK, Grant MG, Forsythe DB. Selecting the appropriate rodent diet for endocrine disruptor research and testing studies. ILAR J. (2004) 45:401-16. doi: 10.1093/ilar.45.4.401

30. Cooke PS, Naaz A. Effects of estrogens and the phytoestrogen genistein on adipogenesis and lipogenesis in males and females. Birth Defects Res A Clin Mol Teratol. (2005) 73 472-3. doi: 10.1002/bdra.20142

31. Kuiper GG, Lemmen JG, Carlsson B, Corton JC, Safe SH, van der Saag PT, et al. Interaction of estrogenic chemicals and phytoestrogens with estrogen receptor beta. Endocrinology (1998) 139:4252-63. doi: 10.1210/endo.139.10.6216

32. Morito K, Hirose T, Kinjo J, Hirakawa T, Okawa M, Nohara T, et al. Interaction of phytoestrogens with estrogen receptors alpha and beta. Biol Pharm Bull. (2001) 24:351-6. doi: 10.1248/bpb.24.351

33. Pettersson K, Delaunay F, Gustafsson JA. Estrogen receptor beta acts as a dominant regulator of estrogen signaling. Oncogene (2000) 19:4970-8. doi: 10.1038/sj.onc.1203828

34. Penza M, Montani C, Romani A, Vignolini P, Pampaloni B, Tanini A, et al. Genistein affects adipose tissue deposition in a dose-dependent 
and gender-specific manner. Endocrinology (2006) 147:5740-51. doi: 10.1210/en.2006-0365

35. Zanella I, Marrazzo E, Biasiotto G, Penza M, Romani A, Vignolini $\mathrm{P}$, et al. Soy and the soy isoflavone genistein promote adipose tissue development in male mice on a low-fat diet. Eur J Nutr. (2015) 54:1095-107. doi: 10.1007/s00394-014-0786-9

36. Ponti G, Rodriguez-Gomez A, Farinetti A, Marraudino M, Filice F, Foglio B, et al. Early postnatal genistein administration permanently affects nitrergic and vasopressinergic systems in a sex-specific way. Neuroscience (2017) 346:203-15. doi: 10.1016/j.neuroscience.2017.01.024

37. Patisaul HB. Endocrine disruption by dietary phyto-oestrogens: impact on dimorphic sexual systems and behaviours. Proc Nutr Soc. (2017) 76:130-44. doi: 10.1017/S0029665116000677

38. Phrakonkham P, Viengchareun S, Belloir C, Lombes M, Artur Y, CanivencLavier MC. Dietary xenoestrogens differentially impair 3T3-L1 preadipocyte differentiation and persistently affect leptin synthesis. J Steroid Biochem Mol Biol. (2008) 110:95-103. doi: 10.1016/j.jsbmb.2008.02.006

39. Rayalam S, Della-Fera MA, Baile CA. Phytochemicals and regulation of the adipocyte life cycle. J Nutr Biochem. (2008) 19:717-26. doi: 10.1016/j.jnutbio.2007.12.007

40. Catmull S, Masood F, Schacht S, Dolan R, Stegman D, Leung L, et al. Dietary genistein rescues reduced basal chloride secretion in diabetic jejunum via sex-dependent mechanisms. Cell Physiol Biochem. (2016) 40:335-46. doi: $10.1159 / 000452549$

41. Schacht S, Masood F, Catmull S, Dolan R, Altabtabaee R, Grow W, et al. Dietary genistein influences number of acetylcholine receptors in female diabetic jejunum. J Diabetes Res. (2017) 2017:3568146. doi: $10.1155 / 2017 / 3568146$

42. Mosqueda-Solis A, Lasa A, Gomez-Zorita S, Eseberri I, Pico C, Portillo MP. Screening of potential anti-adipogenic effects of phenolic compounds showing different chemical structure in 3T3-L1 preadipocytes. Food Funct. (2017):3576-86. doi: 10.1039/C7FO00679A

43. Yang JY, Lee SJ, Park HW, Cha YS. Effect of genistein with carnitine administration on lipid parameters and obesity in C57Bl/6J mice fed a high-fat diet. J Med Food (2006) 9:459-67. doi: 10.1089/jmf.2006.9.459

44. Weigt C, Hertrampf T, Kluxen FM, Flenker U, Hulsemann F, Fritzemeier KH, et al. Molecular effects of ER alpha- and beta-selective agonists on regulation of energy homeostasis in obese female Wistar rats. Mol Cell Endocrinol (2013) 377:147-58. doi: 10.1016/j.mce.2013.07.007

45. Kim HK, Nelson-Dooley C, Della-Fera MA, Yang JY, Zhang W, Duan J, et al. Genistein decreases food intake, body weight, and fat pad weight and causes adipose tissue apoptosis in ovariectomized female mice. J Nutr. (2006) 136:409-14. doi: 10.1093/jn/136.2.409

46. Naaz A, Yellayi S, Zakroczymski MA, Bunick D, Doerge DR, Lubahn DB, et al. The soy isoflavone genistein decreases adipose deposition in mice. Endocrinology (2003) 144:3315-20. doi: 10.1210/en.2003-0076

47. Harmon AW, Harp JB. Differential effects of flavonoids on 3T3-L1 adipogenesis and lipolysis. Am J Physiol Cell Physiol. (2001) 280:C807-13. doi: 10.1152/ajpcell.2001.280.4.C807

48. Dang ZC, Audinot V, Papapoulos SE, Boutin JA, Löwik CW. Peroxisome proliferator-activated receptor gamma (PPARgamma) as a molecular target for the soy phytoestrogen genistein. J Biol Chem. (2003) 278:9627.doi: 10.1074/jbc.M209483200

49. Lee YM, Choi JS, Kim MH, Jung MH, Lee YS, Song J. Effects of dietary genistein on hepatic lipid metabolism and mitochondrial function in mice fed high-fat diets. Nutrition (2006) 22:956-64. doi: 10.1016/j.nut.2005. 12.014

50. Ruhlen RL, Howdeshell KL, Mao J, Taylor JA, Bronson FH, Newbold RR, et al. Low phytoestrogen levels in feed increase fetal serum estradiol resulting in the "fetal estrogenization syndrome" and obesity in CD-1 mice. Environ Health Perspect. (2008) 116:322-8. doi: 10.1289/ehp.10448

51. Newbold RR, Padilla-Banks E, Snyder RJ, Jefferson WN. Developmental exposure to estrogenic compounds and obesity. Birth Defects Res A Clin Mol Teratol (2005) 73:478-80. doi: 10.1002/bdra.20147

52. Strakovsky RS, Lezmi S, Flaws JA, Schantz SL, Pan YX, Helferich WG. Genistein exposure during the early postnatal period favors the development of obesity in female, but not male rats. Toxicol Sci. (2014) 138:161-74. doi: 10.1093/toxsci/kft331
53. Zhang YB, Yan JD, Yang SQ, Guo JP, Zhang X, Sun XX, et al. Maternal genistein intake can reduce body weight in male offspring. Biomed Environ Sci. (2015) 28:769-72.doi: 10.3967/bes2015.107

54. Dolinoy DC, Weidman JR, Waterland RA, Jirtle RL. Maternal genistein alters coat color and protects Avy mouse offspring from obesity by modifying the fetal epigenome. Environ Health Perspect. (2006) 114:567-72. doi: 10.1289/ehp. 8700

55. Marraudino M, Ponti G, Farinetti A, Macchi E, Accornero P, Gotti S, et al. Early postnatal genistein administration has a sexually dimorphic obesogenic effect and organizational effects on hypothalamic neuroendocrine circuits in CD1 mice. In: Carrillo Urbano B, Pinos Sanchez H. editors. 2nd Int. Congress Psychobiology. UNED: Ávila. (2017) pp. 133.

56. Amiot MJ, Riva C, Vinet A. Effects of dietary polyphenols on metabolic syndrome features in humans: a systematic review. Obes Rev. (2016) 17:57386. doi: 10.1111/obr.12409

57. Nielsen IL, Williamson G. Review of the factors affecting bioavailability of soy isoflavones in humans. Nutr Cancer (2007) 57:1-10. doi: 10.1080/01635580701267677

58. Tordjman K, Grinshpan L, Novack L, Goen T, Segev D, Beacher L, et al. Exposure to endocrine disrupting chemicals among residents of a rural vegetarian/vegan community. Environ Int. (2016) 97:68-75. doi: 10.1016/j.envint.2016.10.018

59. Llaneza P, Gonzalez C, Fernandez-Inarrea J, Alonso A, Diaz F, Arnott I, et al. Soy isoflavones, diet and physical exercise modify serum cytokines in healthy obese postmenopausal women. Phytomedicine (2011) 18:245-50. doi: 10.1016/j.phymed.2010.07.011

60. Behloul N, Wu G. Genistein: a promising therapeutic agent for obesity and diabetes treatment. Eur J Pharmacol. (2013) 698:31-8. doi: 10.1016/j.ejphar.2012.11.013

61. Ribeiro E, Ladeira C, Viegas S. Occupational exposure to bisphenol A (BPA): a reality that still needs to be unveiled. Toxics (2017) 5:22. doi: $10.3390 /$ toxics 5030022

62. Legeay S, Faure S. Is bisphenol A an environmental obesogen? Fundam Clin Pharmacol. (2017) 31:594-609. doi: 10.1111/fcp.12300

63. Patisaul HB, Todd KL, Mickens JA, Adewale HB. Impact of neonatal exposure to the ERalpha agonist PPT, bisphenol-A or phytoestrogens on hypothalamic kisspeptin fiber density in male and female rats. Neurotoxicology (2009) 30:350-7. doi: 10.1016/j.neuro.2009.02.010

64. Panzica GC, Bo E, Martini MA, Miceli D, Mura E, Viglietti-Panzica C, et al. Neuropeptides and enzymes are targets for the action of endocrine disrupting chemicals in the vertebrate brain. J Toxicol Environ Health B Crit Rev. (2011) 14:449-72. doi: 10.1080/10937404.2011.578562

65. Marraudino M, Farinetti A, Troisi E, Miceli D, Gotti S, Panzica G. Kisspeptin and Paraventricular Nucleus: Effects of Bisphenol A on CD1 Female Mice, XXV GISN Meeting. Rome (2015). p. 16.

66. Rubin BS. Bisphenol A: an endocrine disruptor with widespread exposure and multiple effects. J Steroid Biochem Mol Biol. (2011) 127:27-34. doi: 10.1016/j.jsbmb.2011.05.002

67. Dhanjai, Sinha A, Wu L, Lu X, Chen J, Jain R. Advances in sensing and biosensing of bisphenols: a review. Anal Chim Acta. (2018) 998:1-27. doi: 10.1016/j.aca.2017.09.048

68. Dhanjai, Sinha A, Wu L, Lu X, Chen J, Jain R. Corrigendum to "advances in sensing and biosensing of bisphenols: a review" (ACA 998 (2018) 1-27). Anal Chim Acta (2018) 1029:125-9. doi: 10.1016/j.aca.2018.05.047

69. Ivry Del Moral L, Le Corre L, Poirier H, Niot I, Truntzer T, Merlin JF, et al. Obesogen effects after perinatal exposure of 4,4'sulfonyldiphenol (Bisphenol S) in C57BL/6 mice. Toxicology (2016) 3578:11-20. doi: 10.1016/j.tox.2016.05.023

70. Boucher JG, Gagne R, Rowan-Carroll A, Boudreau A, Yauk CL, Atlas E. Bisphenol A and Bisphenol S induce distinct transcriptional profiles in differentiating human primary preadipocytes. PLOS ONE (2016) 11:e0163318. doi: 10.1371/journal.pone. 0163318

71. Boucher JG, Ahmed S, Atlas E. Bisphenol S induces adipogenesis in primary human preadipocytes from female donors. Endocrinology (2016) 157:1397407. doi: 10.1210/en.2015-1872

72. Blaustein JD, Gentry RT, Roy EJ, Wade GN. Effects of ovariectomy and estradiol on body weight and food intake in gold thioglucose-treated mice. Physiol Behav. (1976) 17:1027-30. doi: 10.1016/0031-9384(76)90028-7 
73. Geary N, Asarian L, Korach KS, Pfaff DW, Ogawa S. Deficits in E2-dependent control of feeding, weight gain, and cholecystokinin satiation in ER-alpha null mice. Endocrinology (2001) 142:4751-7. doi: 10.1210/endo.142.11.8504

74. Mauvais-Jarvis F, Clegg DJ, Hevener AL. The role of estrogens in control of energy balance and glucose homeostasis. Endocr Rev (2013) 34:309-38. doi: 10.1210/er.2012-1055

75. Allende-Vigo MZ. Women and the metabolic syndrome: an overview of its peculiarities. P R Health Sci J. (2008) 27:190-5. Available online at: http:// prhsj.rcm.upr.edu/index.php/prhsj/article/view/67/51

76. Coyoy A, Guerra-Araiza C, Camacho-Arroyo I. Metabolism regulation by estrogens and their receptors in the central nervous system before and after menopause. Horm Metab Res. (2016) 48:489-96. doi: 10.1055/s-0042-110320

77. Hart-Unger S, Korach KS. Estrogens and obesity: is it all in our heads? Cell Metab. (2011) 14:435-6. doi: 10.1016/j.cmet.2011.09.003

78. Meirelles RM. Menopause and metabolic syndrome. Arq Bras Endocrinol Metabol. (2014) 58:91-6. doi: 10.1590/0004-2730000002909

79. Heine PA, Taylor JA, Iwamoto GA, Lubahn DB, Cooke PS. Increased adipose tissue in male and female estrogen receptor-alpha knockout mice. Proc Natl Acad Sci USA. (2000) 97:12729-34. doi: 10.1073/pnas.97.23.12729

80. Okura T, Koda M, Ando F, Niino N, Ohta S, Shimokata H. Association of polymorphisms in the estrogen receptor alpha gene with body fat distribution. Int J Obes Relat Metab Disord. (2003) 27:1020-7. doi: 10.1038/sj.ijo.0802378

81. Musatov S, Chen W, Pfaff DW, Mobbs CV, Yang XJ, Clegg DJ, et al. Silencing of estrogen receptor alpha in the ventromedial nucleus of hypothalamus leads to metabolic syndrome. Proc Natl Acad Sci USA. (2007) 104:2501-6. doi: 10.1073/pnas.0610787104

82. Diano S, Kalra SP, Sakamoto H, Horvath TL. Leptin receptors in estrogen receptor-containing neurons of the female rat hypothalamus. Brain Res. (1998) 812:256-9. doi: 10.1016/S0006-8993(98)00936-6

83. Clegg DJ, Brown LM, Woods SC, Benoit SC. Gonadal hormones determine sensitivity to central leptin and insulin. Diabetes (2006) 55:978-87. doi: 10.2337/diabetes.55.04.06.db05-1339

84. Marraudino M, Miceli D, Farinetti A, Ponti G, Panzica G, Gotti S. Kisspeptin innervation of the hypothalamic paraventricular nucleus: sexual dimorphism and effect of estrous cycle in female mice. J Anat. (2017) 230:775-86. doi: $10.1111 /$ joa. 12603

85. Marraudino M, Martini M, Trova S, Farinetti A, Ponti G, Gotti S, Panzica G. Kisspeptin system in ovariectomized mice: estradiol and progesterone regulation. Brain Res. (2018) 1688:8-14. doi: 10.1016/j.brainres.2018.03.014

86. Castellano JM, Tena-Sempere M. Metabolic control of female puberty: potential therapeutic targets. Expert Opin Ther Targets (2016) 20:1181-93. doi: 10.1080/14728222.2016.1212015

87. Burke MC, Letts PA, Krajewski SJ, Rance NE. Coexpression of dynorphin and neurokinin B immunoreactivity in the rat hypothalamus: morphologic evidence of interrelated function within the arcuate nucleus. J Comp Neurol. (2006) 498:712-26. doi: 10.1002/cne.21086

88. Smith JT, Clifton DK, Steiner RA. Regulation of the neuroendocrine reproductive axis by kisspeptin-GPR54 signaling. Reproduction (2006) 131:623-30. doi: 10.1530/rep.1.00368

89. Backholer K, Smith JT, Rao A, Pereira A, Iqbal J, Ogawa S, et al. Kisspeptin cells in the ewe brain respond to leptin and communicate with neuropeptide Y and proopiomelanocortin cells. Endocrinology (2010) 151:2233-43. doi: 10.1210/en.2009-1190

90. Higo S, Iijima N, Ozawa H. Characterisation of Kiss1r (Gpr54)-expressing neurones in the arcuate nucleus of the female rat hypothalamus. $J$ Neuroendocrinol. (2017) 29. doi: 10.1111/jne.12452

91. Fu LY, van den Pol AN. Kisspeptin directly excites anorexigenic proopiomelanocortin neurons but inhibits orexigenic neuropeptide Y cells by an indirect synaptic mechanism. J Neurosci. (2010) 30:10205-19. doi: 10.1523/JNEUROSCI.2098-10.2010

92. WHO. Fact Sheet: Obesity and Overweight. WHO Fact Sheet 311 (2014).

93. Callewaert F, Venken K, Ophoff J, De Gendt K, Torcasio A, van Lenthe $\mathrm{GH}$, et al. Differential regulation of bone and body composition in male mice with combined inactivation of androgen and estrogen receptor-alpha. FASEB J. (2009) 23:232-40. doi: 10.1096/fj.08113456
94. Grumbach MM, Auchus RJ. Estrogen: consequences and implications of human mutations in synthesis and action. J Clin Endocrinol Metab. (1999) 84:4677-94. doi: 10.1210/jc.84.12.4677

95. Smith BK, York DA, Bray GA. Chronic cerebroventricular galanin does not induce sustained hyperphagia or obesity. Peptides (1994) 15:1267-72. doi: 10.1016/0196-9781(94)90152-X

96. Finan B, Yang B, Ottaway N, Stemmer K, Muller TD, Yi CX, et al. Targeted estrogen delivery reverses the metabolic syndrome. Nat Med. (2012) 18:1847-56. doi: 10.1038/nm.3009

97. Xu Y, Faulkner LD, Hill JW. Cross-Talk between metabolism and reproduction: the role of POMC and SF1 neurons. Front Endocrinol. (2011) 2:98. doi: 10.3389/fendo.2011.00098

98. Urban JH, Bauer-Dantoin AC, Levine JE. Neuropeptide Y gene expression in the arcuate nucleus: sexual dimorphism and modulation by testosterone. Endocrinology (1993) 132:139-45. doi: 10.1210/endo.132.1.8419120

99. Martini M, Sica M, Gotti S, Eva C, Panzica GC. Effects of estrous cycle and sex on the expression of neuropeptide Y Y1 receptor in discrete hypothalamic and limbic nuclei of transgenic mice. Peptides (2011) 32:13304. doi: 10.1016/j.peptides.2011.04.004

100. Qu F, Zhang D, Chen LT, Wang FF, Pan JX, Zhu YM, et al. Auricular acupressure reduces anxiety levels and improves outcomes of in vitro fertilization: a prospective, randomized and controlled study. Sci Rep. (2014) 4:5028. doi: 10.1038/srep05028

101. Gelez H, Poirier S, Facchinetti P, Allers KA, Wayman C, Bernabe J, et al. Neuroanatomical distribution of the melanocortin-4 receptors in male and female rodent brain. J Chem Neuroanat. (2010) 40:310-24. doi: 10.1016/j.jchemneu.2010.09.002

102. Grun F. The obesogen tributyltin. Vitam Horm. (2014) 94:277-325. doi: 10.1016/B978-0-12-800095-3.00011-0

103. Marques VB, Faria RA, Dos Santos L. Overview of the pathophysiological implications of organotins on the endocrine system. Front Endocrinol. (2018) 9:101. doi: 10.3389/fendo.2018.00101

104. Ferraz da Silva, Freitas-Lima LC, Graceli JB, Rodrigues LCM. Organotins in neuronal damage, brain function, and behavior: a short review. Front Endocrinol. (2017) 8:366. doi: 10.3389/fendo.2017.00366

105. Santos-Silva AP, Andrade MN, Pereira-Rodrigues P, Paiva-Melo FD, Soares P, Graceli JB, et al. Frontiers in endocrine disruption: Impacts of organotin on the hypothalamus-pituitary-thyroid axis. Mol Cell Endocrinol. (2018) 460:246-57. doi: 10.1016/j.mce.2017.07.038

106. Decherf S, Demeneix BA. The obesogen hypothesis: a shift of focus from the periphery to the hypothalamus. J Toxicol Environ Health B Crit Rev. (2011) 14:423-48. doi: 10.1080/10937404.2011.578561

107. Satoh K, Nagai F, Aoki N. Several environmental pollutants have binding affinities for both androgen receptor and estrogen receptor a. J Health Sci. (2001) 47:495-501. doi: 10.1248/jhs.47.495

108. Nakanishi T. Endocrine disruption induced by organotin compounds; organotins function as a powerful agonist for nuclear receptors rather than an aromatase inhibitor. J Toxicol Sci. (2008) 33:269-76. doi: $10.2131 /$ jts.33.269

109. Grun F, Blumberg B. Endocrine disrupters as obesogens. Mol Cell Endocrinol. (2009) 304:19-29. doi: 10.1016/j.mce.2009.02.018

110. Moreno S, Farioli-Vecchioli S, Ceru MP. Immunolocalization of peroxisome proliferator-activated receptors and retinoid $\mathrm{X}$ receptors in the adult rat CNS. Neuroscience (2004) 123:131-45. doi: 10.1016/j.neuroscience.2003. 08.064

111. Ryan KK, Li B, Grayson BE, Matter EK, Woods SC, Seeley RJ. A role for central nervous system PPAR-gamma in the regulation of energy balance. Nat Med (2011) 17:623-6. doi: 10.1038/nm.2349

112. Sena GC, Freitas-Lima LC, Merlo E, Podratz PL, de Araujo JF, Brandao PA, et al. Environmental obesogen tributyltin chloride leads to abnormal hypothalamic-pituitary-gonadal axis function by disruption in kisspeptin/leptin signaling in female rats. Toxicol Appl Pharmacol. (2017) 319:22-38. doi: 10.1016/j.taap.2017.01.021

113. Incollingo Rodriguez AC, Epel ES, White ML, Standen EC, Seckl JR, Tomiyama AJ. Hypothalamic-pituitary-adrenal axis dysregulation and cortisol activity in obesity: a systematic review. Psychoneuroendocrinology (2015) 62:301-18. doi: 10.1016/j.psyneuen.2015.08.014 
114. Merlo E, Podratz PL, Sena GC, de Araujo JF, Lima LC, Alves IS, et al. The environmental pollutant tributyltin chloride disrupts the hypothalamicpituitary-adrenal axis at different levels in female rats. Endocrinology (2016) 157:2978-95. doi: 10.1210/en.2015-1896

115. Adeeko A, Li D, Forsyth DS, Casey V, Cooke GM, Barthelemy J, et al. Effects of in utero tributyltin chloride exposure in the rat on pregnancy outcome. Toxicol Sci. (2003) 74:407-15. doi: 10.1093/toxsci/kfg131

116. Rodrigues-Pereira P, Palmero C, Medina de MAttos R, Gran da Silva DLS, Graceli JB, Santos-Silva AP, et al. Influence of organotin on thyroid morphophysiological status. Environ Health Sci. (2015) 1:1-7. doi: 10.15436/2378-6841.15.01815.018

117. Sharan S, Nikhil K, Roy P. Disruption of thyroid hormone functions by low dose exposure of tributyltin: an in vitro and in vivo approach. Gen Comp Endocrinol. (2014) 206:155-65. doi: 10.1016/j.ygcen.2014.07.027

118. Decherf S, Seugnet I, Fini JB, Clerget-Froidevaux MS, Demeneix BA. Disruption of thyroid hormone-dependent hypothalamic set-points by environmental contaminants. Mol Cell Endocrinol. (2010) 323:172-82. doi: 10.1016/j.mce.2010.04.010

119. Ochoa-Reparaz J, Kasper LH. The second brain: is the gut microbiota a link between obesity and central nervous system disorders? Curr Obes Rep. (2016) 5:51-64. doi: 10.1007/s13679-016-0191-1

120. Guo H, Yan H, Cheng D, Wei X, Kou R, Si J. Tributyltin exposure induces gut microbiome dysbiosis with increased body weight gain and dyslipidemia in mice. Environ Toxicol Pharmacol. (2018) 60:202-8. doi: 10.1016/j.etap.2018.04.020
121. Regnier SM, El-Hashani E, Kamau W, Zhang X, Massad NL, Sargis RM Tributyltin differentially promotes development of a phenotypically distinct adipocyte. Obesity (2015) 23:1864-71. doi: 10.1002/oby. 21174

122. Yanik SC, Baker AH, Mann KK, Schlezinger JJ. Organotins are potent activators of PPARgamma and adipocyte differentiation in bone marrow multipotent mesenchymal stromal cells. Toxicol Sci (2011) 122:476-88. doi: $10.1093 /$ toxsci/kfr 140

123. Decherf S, Seugnet I, Kouidhi S, Lopez-Juarez A, Clerget-Froidevaux MS, Demeneix BA. Thyroid hormone exerts negative feedback on hypothalamic type 4 melanocortin receptor expression. Proc Natl Acad Sci USA. (2010) 107:4471-6. doi: 10.1073/pnas.09051 90107

Conflict of Interest Statement: The authors declare that the research was conducted in the absence of any commercial or financial relationships that could be construed as a potential conflict of interest.

Copyright (c) 2019 Marraudino, Bonaldo, Farinetti, Panzica, Ponti and Gotti. This is an open-access article distributed under the terms of the Creative Commons Attribution License (CC BY). The use, distribution or reproduction in other forums is permitted, provided the original author(s) and the copyright owner(s) are credited and that the original publication in this journal is cited, in accordance with accepted academic practice. No use, distribution or reproduction is permitted which does not comply with these terms. 